\title{
İmmünfloresan Yöntemi ile Belirlenen Otoantikorlarda Kadın/Erkek Dağılımı
}

\author{
Female-Male Distribution in Autoantibody Detected by Immunofluorescence
}

\author{
Nuray Gürel-Polat ${ }^{1} \stackrel{(D)}{ }$, Nurhas Safran ${ }^{1}\left(\mathbb{D}\right.$, , Gaye Erten-Yurdagül $^{2}$ \\ IIstanbul Üniversitesi, İstanbul Tıp Fakültesi, Tıbbi Mikrobiyoloji Anabilim Dalı, Viroloji ve Temel Immünoloji Bilim Dalı, İstanbul, Türkiye \\ ${ }^{2}$ Istanbul Üniversitesi, Aziz Sancar Deneysel Tıp Araştırma Enstitüsü Immünoloji Anabilim Dalı, İstanbul, Türkiye
}

ORCID ID: N.G.P. 0000-0002-5513-575X; N.S. 0000-0002-0239-1151; G.E.Y. 0000-0002-5784-7785

Cite this article as: Gürel-Polat N, Safran N, Erten-Yurdagül G. Immünfloresan yöntemi ile belirlenen otoantikorlarda kadın/erkek dağılımı. Experimed 2020; 10(3): 119-23.

\section{öz}

Amaç: Otoimmün hastalıkların tanısında ve takibinde kullanılan otoantikorlardan olan anti-nükleer antikorların ve organ spesifik olmayan antikorların pozitiflik oranları, kadın/erkek hastalardaki dağılımını saptamaktır.

Gereç ve Yöntemler: Çalışmamızda retrospektif olarak 2016-2017 yılları arasında laboratuvarımıza başvuran hastaların serum örneklerinde immunfloresans (IFA) yöntemi ile çalışılan anti-nükleer antikor (ANA), anti-nötrofil sitoplazmik antikor (ANCA), anti-düz kas antikorları (ASMA), anti-karaciğer böbrek mikrozomal antikorları (anti-LKM1), anti-gastrik pariyetal hücre antikorları (anti-GPCA) ve anti-mitokondriyal antikorlar (AMA) gibi otoantikor değerleri taranmıştır. ANA, HEp-2 hücre soyu ile ASMA, AMA LKM-1 ve GPCA'ları sıçan karaciğer, böbrek, mide dokusunu içeren kombine preparatlar kullanılarak; ANCA ise etanol ile fikse edilmiş insan nötrofil preparatları substrat olarak kullanılmıştır. ANA için 1/80, ASMA AMA, LKM-1, GPCA için serum sulandırımı 1/40; ANCA için ise 1/20 ve üzeri pozitif olarak kabul edilmiştir. Ek olarak, pozitif örneklerde patern özellikleri ve dilüsyon miktarları da değerlendirilmiştir.

Bulgular: IFA yöntemi ile çalışıımış 5378'si kadın, 3055'ü erkek (toplam 8433) hastanın serumlarında otoantikor test sonuçları incelenmiştir. ANA patern özelliği en yoğun olarak homojen tip başta olmak üzere benekli (speckled), granüler, sentromer, nükleolar, periferik ve nükleer tanecikler şeklindedir. Kadın hastaların pozitiflik değerleri erkek hastalara göre yüksek saptanmıştır.

Sonuç: Değerlendirmemiz sonucunda, kadın hasta sayısının fazla olduğu ve kadınlardaki pozitiflik oranlarının da erkek hastaların iki veya üç katı oranında olduğu gözlenmiştir.

Anahtar Kelimeler: Antinükleer antikor, ANA, organ spesifik olmayan otoantikorlar, immunfloresans, IFA

\begin{abstract}
Objective: This study determines the positivity rates and gender distribution of antinuclear and liver-specific autoantibodies that are considered important in the diagnosis and follow-up of autoimmune diseases.
\end{abstract}

Material and Method: We retrospectively screened autoantibodies, including antinuclear antibodies (ANA), antineutrophil cytoplasmic antibody (ANCA), anti-smooth muscle antibodies (ASMA), anti-liver kidney microsomal-1 antibodies (anti-LKM-1), anti-gastric parietal cell antibodies (anti-GPCA), and antimitochondrial antibodies (AMA) in serum samples of patients applied to our laboratory during 2015-2016 by immunofluorescence methodology. We used the Hep2 cell line for ANA, rat liver-kidney-stomach combined tissues for LKM-1, ASMA, GPCA and AMA, and ethanol fixed human granulocytes preparations for ANCA. Dilutions $\geq 1 / 80$ for ANA, $\geq 1 / 40$ for ASMA, AMA, LKM-1, GPCA, and $\geq 1 / 20$ for ANCA were positive. Positive samples were also evaluated for their staining patterns and dilutions.

Results: Autoantibody test results studied with immunofluorescence were screened in 8433 (5378 females and 3055 males) samples. The highest staining pattern observed for ANA was homogenous, followed by speckled, granular, centromere, nucleolar, peripheral, and nuclear speckled. Females exhibited a higher positivity rate than males.

Conclusion: The number and positivity rate of female patients were found to be two to three times higher than those of male patients.

Keywords: Antinuclear antibody, ANA, non-organ-specific autoantibody, immunofluorescence assay, IFA 


\section{GíRiş}

Sistemik otoimmün hastalıklar bir veya birden çok sayıda otoantikor oluşumuyla ortaya çıkmaktadır. Hücre yüzeyi, nukleusu ya da sitoplazmada bulunan çeşitli bileşenlere karşı gelişen bu antikorlar, otoimmün hastalıkların $(\mathrm{O} \mathrm{iH})$ tanı ve izlenme sürecinde önemli rol oynamaktadır (1). Hücre nukleusuna karşı oluşan otoantikorlara anti-nükleer antikorlar (ANA) adı verilmektedir (2). ANA'ların serolojik olarak tanımlanması romatolojik hastalıklarda (3) olduğu kadar, viral $(4,5)$, malign (6) ve organ-spesifik hastalıklar (7) gibi birçok durumda da önem kazanmaktadır. Otoantikorların tanımlanması ve gösterilmesi, klinik tıp ve klinik immünolojinin önemli bir bölümünü oluşturmaktadır. Sistemik ve organ-spesifik otoimmün hastalıkların tanısında otoantikor tayini için immünfloresans (IFA) metodu kullanılmaktadır. Günümüzde doku kesitleri ve HEp-2 hücreleri 100'den fazla otoantikorun tanımlanmasına olanak sağlamaktadır. IFA testi; zahmetli ve değerlendirilmesinin subjektif olması, hücre komponentlerinin boyanma kalıpları (patern) ile antijen tiplerinin kesin ayrımının yapılamaması gibi dezavantajlara sahip olmakla birlikte, maliyet açısından avantajlı konumdadır (8).

Anti-mitokondriyal (AMA) ve anti-karaciğer/böbrek/mikrozom antikorları (anti-LKM-1) ise otoimmün hepatit; anti-düz kas antikoru (ASMA-DKA) hepatit ve otoimmün hepatit serolojisinde önemli otoantikorlardır (9). Otoimmün anemi tanısında ise anti-gastrik pariyetal hücre antikorunun (anti-GPCA) önemi büyüktür (9).

Anti-nötrofil sitoplazmik antikorlar (ANCA), vaskülit ve Wegener granülomatoz hastalığının tanısında önemli rol oynayan antikorlardır. İnsan nötrofillerinin etanol ile fiksasyonu sonucu hazırlanan preparatlarda sitoplazmada bulunan enzimlere karşı oluşan otoantikorlar tespit edilmektedir. Boyanma özelliklerine göre periferik ANCA ( $p-A N C A$ ) ve sitoplazmik ANCA (c-ANCA) olmak üzere iki tipi bulunmaktadır (10).

\section{GEREÇ VE YÖNTEM}

Bu çalışmada 2016 nisan - 2017 nisan aylarında İstanbul Üniversitesi, İstanbul Tıp Fakültesi Tıbbi Mikrobiyoloji Anabilim Dalı, Viroloji ve Temel İmmünoloji Bilim Dalı, İmmünoloji Laboratuvarına farklı klinik ve polikliniklerden başvuran, 18-75 yaşları arasındaki 8433 hastanın (5378 kadın, 3055 erkek) serum sonuçları retrospektif olarak taranmıştır. Kadın erkek oranı yaklaşık 2:1 dir. Otoantikorlardan ANA, HEp-2 hücre soyu (Euroimmün, Lübeck-Almanya) ile ASMA, AMA, LKM-1 ve GPCA'ları sıçan karaciğer, böbrek, mide dokusunu içeren kombine preparatlar (Euroimmün, Lübeck-Almanya) kullanılarak; ANCA ise etanol ile fikse edilmiş insan nötrofil (Euroimmun, Lübeck-Almanya) preparatlarının (Euroimmün, Lübeck-Almanya) substrat olarak kullanıldığı IFA yöntemi ile değerlendirilmiştir. ANA için 1/80, ASMA, AMA, LKM-1, GPCA için serum sulandırımı 1/40; ANCA için ise $1 / 20$ ve üzeri pozitif olarak kabul edilmiştir. IFA yöntemi ile çalışılan testlerde serum örnekleri, fosfat tamponlu izotonik solüsyon (PBS) ile sulandırılmış ve lam üzerindeki kuyucuklara 50-70 $\mu$ l konulup, oda ısısında nemli ortamda 30 dakika inkübe edilmiştir. İnkübasyon sonrasında lamlar 5 dakika PBS içinde bekletilerek yıkanmıştır. Floresan işaretli anti-insan immünoglobülin G (IgG; Euroimmün, Lübeck-Almanya) ile tekrar inkübe edilmiştir. Lamlar yıkama işlemi tekrarlandıktan sonra kapatma solüsyonu (Gliserol içeren PBS) damlatılarak lamel ile kapatılmıştır. Hazırlanan örnekler floresan mikroskobunda (EuroStar II, Almanya) önce X20 sonra X40 objektifler ile değerlendirilerek boyanma kalıp özellikleri belirlenmiştir. Pozitif bulunan örneklerin ileri sulandırımları hazırlanarak titreleri saptanmıştır.

ANA pozitif örneklerin ileri seri dilüsyonları (1:160, 1:320, 1:640, 1:1280, 1:2560, 1:5120) yapılarak pozitiflik derecesi belirlenmiş; nükleer antijenlere karşı yeşil floresan ışıma veren otoantikorların farklı boyanma özelliği homojen, speckled (benekli), sentromer, nükleolar olarak ayrıca tanımlanmıştır.

ANCA, nukleus membranında görülen bant boyanması ile pANCA, sitoplazmadaki tanecikler şeklinde görülen boyanma ile cANCA olarak tanımlanmıştır. pANCA pozitifliğinin kesinliği formalin fikse nötrofiller ile hazırlanan preparatlarla tekrarlanarak boyanma özelliği takip edilmiştir.

Kombine preparatlarda böbrek, karaciğer ve midede bulunan hücrelerin mitokondrilerinin boyanması ile gözlenen pozitiflik AMA değerlendirilmesinde kullanılmıştır. LKM-1 antikoru aynı preparatın karaciğer ve böbrek dokusundaki mikrozomların; ASMA midede bulunan kas lifleri muskularis mukosa ve kan damarlarının kas tabakasının verdiği floresans ile tanımlanmıştır. GPCA ise mide bez hücrelerinin boyanması ile değerlendirilmiştir.

\section{BULGULAR}

Viroloji ve Temel İmmünoloji Bilim Dalı, İmmünoloji Laboratuvarı'na fakültemizin ve çevre hastanelerin çeşitli klinik ve polikliniklerinden gönderilen hasta serumlarında otoantikor düzeyleri retrospektif olarak taranmıştır. Çalışma kapsamında 5378 (\%64) kadın ve 3055 (\%36) erkek olmak üzere toplam 8433 hasta sonucu incelenmiştir. İncelenen antikorlar tek tek değerlendirildiğinde; ANA için 5600 (\%66), ANCA için 428 (\%5), AMA için 842 (\%10), ASMA için 1004 (\%12), GPCA için 215 (\%2,5) ve LKM1 için ise 344 (\%4) örnek değerlendirilmiştir (Şekil 1, Şekil 2).

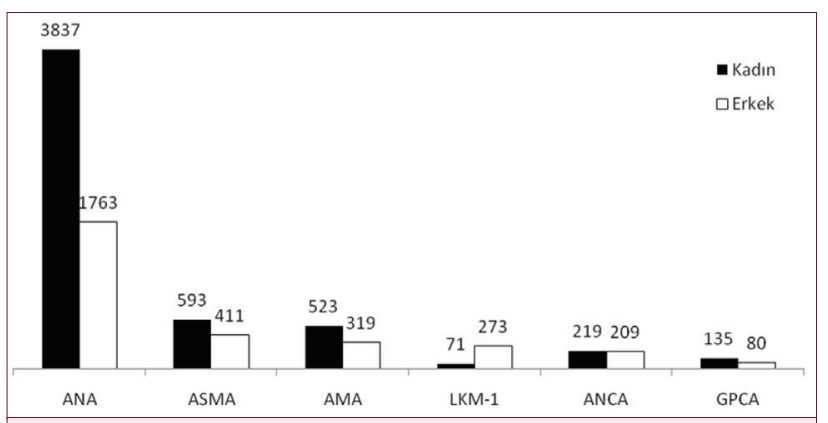

Şekil 1. Otoantikor analizlerinde saptanan pozitifliklerin cinsiyete göre dağılımları. ANA (Anti-nükleer antikor); ASMA (Anti-düz kas antikoru); AMA (Anti-mitokondriyal antikor); LKM-1 (Karaciğer böbrek mikrozom-1); ANCA (Anti-nötrofil sitoplazmik antikor); GPCA (Gastrik pariyetal hücre antikoru). 


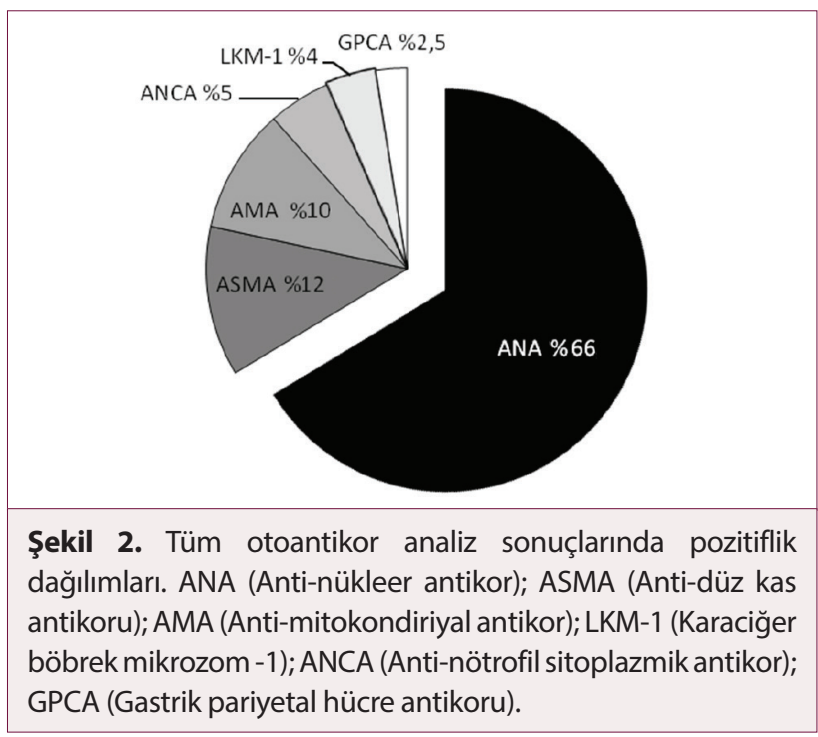

Çalışmamızda tüm örneklerde $\% 84$ negatif, $\% 16$ pozitif sonuç elde edilmiștir. Taranan testler içinde negatiflik oranı erkeklerde $\% 38$ iken, pozitiflik oranı $\% 29$ 'dur. Kadınlarda $\% 62$ olan negatiflik değerine karşlık, $\% 71$ pozitif değer saptanmıştır. ANA incelemesinde 3837'si $(\% 68,5)$ kadın, 1763'ü ise $(\% 31,4)$ erkek olgulardan oluşan toplam 5600 örnek incelenmiştir. Pozitif saptanma oranı kadınlarda \%50,3 olarak saptanmıştır; bu oran erkeklerdeki pozitiflik oranının yaklaşık 3 katıdır. Pozitif örneklerde saptanan ANA patern özelliği de çeşitlilik göstermektedir. En yoğun görülen özellik homojen tipte olup, 417 kadın (\%77) olguda gözlenmiştir. Bu oranı kadın olgularda $103(\% 73,5)$ örnekle benekli ve sırasıyla; granüler $(\% 58,1)$, sentromer $(\% 78,8)$, nukleolar $(\% 74,5)$, nükleer tanecikler $(\% 63)$ ve periferik $(\% 85,1)$ paternlerin izlediği saptanmıştır. Erkek hastalarımızda 238 olguda elde edilen pozitiflik oranı \%17,1 olarak bulunmuştur. Pozitif ANA patern özelliğinde homojen tip $(\% 22,9)$ örnekler arasında ilk sırada saptanmıştır. Bunu benekli $(\% 26,4)$, granüler $(\% 41,8)$, nükleer tanecikler $(\% 36,9)$, nükleolar $(\% 25,4)$, sentromer $(\% 21,1)$ ve periferik $(\% 14,8)$ tipin izlediği gözlenmiştir (Tablo 1, Tablo 2).

ANCA testi 219 kadın ve 209 erkek olmak üzere toplam 428 olguda taranmıştır. ANCA pozitifliğinin toplam pozitif örnekler içindeki değeri $\% 11,6$ 'dır; bu pozitifliğin $\% 2,1^{\prime} i$ kadın, $\% 0,1^{\prime} i$ ise erkek örnekler ile elde edilmiştir, cinsiyet olarak kadınlardaki pozitiflik erkeklerde elde edilen oranın yirmi katıdır.

Otoimmün anemide önemli rol oynayan anti-GPCA toplam pozitiflik içinde kadınlarda \%3,1 iken, erkeklerde \%1 olarak saptanmıştır ve kadınlar erkeklere göre üç katı fazla pozitiflik göstermektedir.

Tablo 1. Otoantikor analiz sonuçları.

\begin{tabular}{|c|c|c|c|c|c|c|c|}
\hline$\%$ & & $\begin{array}{c}\text { ANA } \\
(\%)\end{array}$ & $\begin{array}{c}\text { ASMA } \\
(\%)\end{array}$ & $\begin{array}{c}\text { AMA } \\
(\%)\end{array}$ & $\begin{array}{c}\text { LKM-1 } \\
\text { (\%) }\end{array}$ & $\begin{array}{c}\text { ANCA } \\
\text { (\%) }\end{array}$ & $\begin{array}{c}\text { GPCA } \\
(\%)\end{array}$ \\
\hline \multirow{2}{*}{$\begin{array}{l}\text { Negatif } \\
7048 \\
(84)\end{array}$} & Kadın & $\begin{array}{c}3140 \\
(56,07)\end{array}$ & $\begin{array}{c}429 \\
(42,72)\end{array}$ & $\begin{array}{c}498 \\
(59,14)\end{array}$ & $\begin{array}{c}48 \\
(13,9)\end{array}$ & $\begin{array}{c}189 \\
(44,5)\end{array}$ & $\begin{array}{c}92 \\
(42,79)\end{array}$ \\
\hline & Erkek & $\begin{array}{c}1525 \\
(27,23)\end{array}$ & $\begin{array}{c}290 \\
(28,88)\end{array}$ & $\begin{array}{c}311 \\
(36,93)\end{array}$ & $\begin{array}{c}271 \\
(78,7)\end{array}$ & $\begin{array}{c}189 \\
(44,5)\end{array}$ & $\begin{array}{c}66 \\
(30,69)\end{array}$ \\
\hline \multirow{2}{*}{$\begin{array}{l}\text { Pozitif } \\
1385 \\
(16)\end{array}$} & Kadın & $\begin{array}{c}697 \\
(12,44)\end{array}$ & $\begin{array}{c}164 \\
(16,33)\end{array}$ & $\begin{array}{c}25 \\
(2,96)\end{array}$ & $\begin{array}{c}23 \\
(6,6)\end{array}$ & $\begin{array}{l}30 \\
(7)\end{array}$ & $\begin{array}{c}43 \\
(20)\end{array}$ \\
\hline & Erkek & $\begin{array}{c}238 \\
(4,25)\end{array}$ & $\begin{array}{c}121 \\
(12,05)\end{array}$ & $\begin{array}{c}8 \\
(0,95)\end{array}$ & $\begin{array}{c}2 \\
(0,58)\end{array}$ & $\begin{array}{c}20 \\
(4,67)\end{array}$ & $\begin{array}{c}14 \\
(6,51)\end{array}$ \\
\hline Toplam & & 5600 & 1004 & 842 & 344 & 428 & 215 \\
\hline
\end{tabular}

ANA: Anti-nükleer antikor; ASMA: Anti-düz kas antikoru; AMA: Anti-mitokondiriyal antikor; LKM-1: Karaciğer böbrek mikrozom -1; ANCA: Anti-nötrofil sitoplazmik antikor; GPCA: Gastrik pariyetal hücre antikoru

Tablo 2. Anti-nükleer antikorun boyanma özelliklerinin cinsiyete göre dağılımı.

\begin{tabular}{|c|c|c|c|c|c|c|c|}
\hline & $\begin{array}{c}\text { Homojen } \\
(\%)\end{array}$ & $\begin{array}{l}\text { Benekli } \\
(\%)\end{array}$ & $\begin{array}{c}\text { Sentromer } \\
(\%)\end{array}$ & $\begin{array}{c}\text { Nükleolar } \\
(\%)\end{array}$ & $\begin{array}{l}\text { Periferik } \\
(\%)\end{array}$ & $\begin{array}{c}\text { Granüler } \\
\text { (\%) }\end{array}$ & $\begin{array}{c}\text { Nükleer } \\
\text { Tanecikler (\%) }\end{array}$ \\
\hline \multirow{2}{*}{ Kadın } & 417 & 103 & 41 & 41 & 23 & 43 & 29 \\
\hline & (77) & $(73,5)$ & $(78,8)$ & $(74,5)$ & $(85,1)$ & $(58,1)$ & (63) \\
\hline \multirow{2}{*}{ Erkek } & 124 & 37 & 11 & 14 & 4 & 31 & 17 \\
\hline & $(22,9)$ & $(26,4)$ & $(21,1)$ & $(25,4)$ & $(14,8)$ & $(41,8)$ & $(36,9)$ \\
\hline
\end{tabular}


Otoimmün hepatit (OIH) panelinde önemli rol oynayan ASMA pozitifliği, toplam pozitiflik içinde kadınlarda \%11,8 iken erkeklerde $\% 8,7$ olup, anti-LKM-1antikorlarında ise kadınlarda $(\% 1,6)$ erkeklerin $(\% 0,1) 4$ katı oranında daha yüksek gözlenmiştir. Aynı oran AMA için kadınlarda yaklaşık 4 kat daha yüksektir (kadınlarda \%1,8, erkeklerde ise \%0,5).

Çalışılan tüm otoantikorların kadınlarda pozitiflik ve negatiflik oranları erkeklere göre yüksek bulunmuştur. Bu bulgunun elde edilmesindeki ana nedenin otoimmün hastalıkların kadınlarda daha yüksek oranda görülmesi olduğu açıktır.

\section{TARTIŞMA}

ANA terimi DNA, ribonükleik asit (RNA) ve çeşitli proteinler ile RNP içeren hücre nukleuslarının bileşenleri ile reaksiyona giren antikorların çeşitliliğini ifade etmekte ve tarama testi olarak yaygın şekilde kullanılmaktadır. Bu antikorlar, konnektif doku ve romatizmal hastalığı olan, özellikle sistemik lupus eritematozus (SLE) hastalarında yüksek sıklıkta görülmektedir (11). Genellikle bütün SLE hastalarında (12); ve romatoid artrit, skleroderma ve dermatomyositis gibi diğer konnektif doku hastalığına (KDH) sahip hastalarda sıklıkla ANA pozitifliği bildirilmiştir (7). ANA, çeşitli yanıklar veya viral infeksiyonlar $(4,5)$ sonrasında görülebildiği gibi, bazı sağlıklı kişilerde özellikle yaşıı bireylerde de bulunabilmektedir. Sağlıklı kişilerin $1 / 3$ 'ünde $1 / 40$ dilüsyonda, $1 / 20$ 'sinde ise $1 / 160$ dilüsyonda (13); otoimmün veya inflamatuvar hastalığı olmayan 108 çocukta 1/20 serum dilüsyonuyla yapılan bir başka çalışmada ise \%22 oranında (14) ANA pozitifliği bildirilmiş, ancak ANA ile birlikte dsDNA ve ENA pozitifliği gözlenmemiştir. Deane ve arkadaşlarına (15) ait 15 yıllık retrospektif çalışmada tüm sistemik romatoid hastalıklarda ANA düzeyi yüksek bulunmuştur, bazen de özel ANA spesifisitesi ve özel romatoid hastalık arasındaki ilişki kaybedilmiştir. Bundan dolayı ANA'un ayırımı ve tanımı klinisyenler için teşhisin onayı ve tedavinin takibinde destek bilgi açısından yardımcı olmaktadır (1). OïH genellikle kadınlarda daha sık görülmektedir $(7,16)$. Yaptığımız çalışmada toplam olarak saptanan 933 ANA pozitif olgu $697(\% 50,3)$ kadın hastalar ile $236(\% 17,1)$ erkek hastadan elde edilmiştir. ANA çalışmasına alınan toplam 5600 olguda cinsiyete göre pozitiflik oranları kadınlarda \%50,3 ile erkeklerin $(\% 17,1)$ yaklaşık 3 katıdır. Bu oranın yakın değerler incelenen diğer otoantikorlarda gözlenmektedir (Tablo 1).

KDH'nın tanısında ANA pozitifliği yeterli olmayıp bu pozitifliğin paterninin ve titrasyonunun belirlenmesi gerekmektedir. Sağlıklı insanlarda bile ANA pozitifliği gözlenmesi nedeniyle, titrasyonun $1 / 160$ 'dan büyük olması klinik açısından önemli kabul edilmektedir (17). Pozitif patern özelliği SLE'de en çok homojen, $\mathrm{KDH}$ hastalarında ise benekli şeklindedir. Ayrıca SLE'de dsDNA antikorları da çok önemlidir ve spesifik bir test olup kesin tanı kriteridir $(9,12)$. Tip 1 ve kriptojenik OiH'de yüksek oranda ANA otoantikoru pozitif görülmekte, bunu ASMA ve pANCA pozitifliği izlemektedir. Ancak dsDNA ve organ-spesifik otoantikorlardan anti-tiroid, anti-over ve anti-adrenal antikorları negatif bulunmuştur (18).
ANA'ların nükleer ve sitoplazmik floresan boyanma özelliklerindeki çeşitlilik örneklerde varolan otoantikorların relatif miktarı ve tiplerine bağlı olarak görülmektedir. Floresans boyanma özelliklerine göre ANA pozitif analizi homojen, benekli, sentromer, nükleolar, periferik, granüler ve nükleer tanecikler şeklinde karakteristikler göstermektedir $(1,19)$. Tablo 2'de floresans boyanma karakteristik değerleri görülmektedir.

AMA sıklıkla primer bilier siroz ile ilişkili olarak tanımlanır. AMA'nın düşük titrasyonu kronik aktif hepatit ve kriptojenik siroz gibi diğer karaciğer hastalıklarında tanımlanmıştır. ASMA, kronik aktif hepatitli hastaların \%70'inin serumlarında yüksek titrasyonlarda bulunur. Düşük ASMA titrasyonu viral infeksiyonlar, maligniteler ve sağlıklı kişilerde bulunabilmektedir. GPCA ise pernisiyöz anemili hasta serumlarında \%90 oranında gözlenmektedir. Diğer klinik ve laboratuvar bilgileri ile pozitif GPCA sonucu diğer megaloblastik anemilerden otoimmün pernisiyöz anemi ayırımında yardımcı olur. Yirmi yaşın altındaki normal popülasyonun \%2'sinden daha azında tanımlanmasına rağmen GPCA'un insidansı 40 yaşın üzerindeki kadınlarda artış göstermekte ve 60 yaşın üstündeki normal popülasyonun \%16 değerlerine kadar yükselmektedir (7). Wegener granülomatozu, mikroskobik polianjitis, Churg-Strauss sendromu gibi nekrotizan vaskülitlerin, primer sklerozan kolanjit ve primer bilier sirozun teşhisinde ANCA testi kullanılmaktadır (20).

Tip1 otoimmün hepatit, ANA veya ASMA veya her ikisinin birlikte pozitifliği ile karakterizedir. Hasta popülasyonu \%70 kadınlardan oluşmaktadır. Tip 2 otoimmün hepatit ise hasta serum örneklerinde karaciğer/böbrek mikrozomal tip 1 (LKM-1) antikorunun varlığı ile karakterizedir. Tip 2 otoimmün hepatit hastaları tip 1 hastalardan farklılıklar göstermektedir, bu hastalarda yüksek oranda örneğin tiroid, pariyetal hücre veya Langerhans adacıklarına karşı oluşan antikorlar gibi organ-spesifik otoantikorlar mevcuttur (21).

Hepatit C virüsü ile infekte olan kişilerde romatoid faktör, ANA, kardiyolipin, tiroid ve LKM-1 otoantikorları da gözlenmiştir $(5,22)$. Antikora bağlı otoimmün karaciğer hastalıklarından biri olan primer bilier sirozda (PBC) AMA, primer sklerozan kolanjitde ise PANCA testleri önemlidir, PBC olgularında IFA incelemesi ile ANA nükleer tanecikler olarak tanımlanır (23).

Kamalı ve arkadaşları, 10 yıl süresince kliniklerine başvuran hastalara ait serolojik inceleme sonucunda \%94 oranında ANA pozitifliğini göstermişler, ancak tüm hastalarda dsDNA otoantikorunun negatif olduğunu belirtmişlerdir (24).

$\mathrm{KDH}$ olgularıyla yapılan çalışmada ANA, dsDNA antikorlarının pozitiflik oranı sırasıyla \%96,5 ve \%7,95 bulunmuştur (25). Yapılan bir başka retrospektif çalışmada ise ANA pozitifliği \%28,2; ANA pozitif serumlardaki anti-ENA pozitifliği ise $\% 60,5$ olarak saptanmıştır (26).

Sonuç olarak, taramamız sonucunda ANA testinin oran olarak yüksek sayıda olduğu saptandı. ANA patern özelliğinin homojen tip başta olmak üzere diğer boyanma özelliklerinin izlediğini ve kadın hastalarda erkek hastalara göre oranlarının yüksek 
olduğunu gözlemlendi. Çalıştığımız tüm otoantikorlarda bu oranın kadın hastalarda daha büyük oranda olduğunu literatüre paralel olarak gösterildi.

Etik Komite Onayı: Çalışmada 2016-2017 yıllarına ait örneklerde retrospektif tarama yapıldığından etik kurul onayı alınmamıştır.

Hakem Değerlendirmesi: Dış bağımsız.

Yazar Katkıları: Çalışma Konsepti/Tasarımı - N.G.P., N.S., G.Y.Y.; Veri Toplama - N.G.P., N.S., G.Y.Y.; Veri Analizi/Yorumlama - N.G.P., N.S., G.Y.Y.; Literatür Tarama - N.G.P., N.S., G.Y.Y.; Yazım - N.G.P., N.S., G.Y.Y.

Çıkar Çatışması: Yazarlar çıkar çatışması bildirmemişlerdir.

Finansal Destek: Yazarlar bu çalışmada finansal destek almadıklarını beyan etmişlerdir.

Ethics Committee Approval: There was no ethics committee approval because of the samples belonging to the years 2016-2017 were retrospectively scanned in the study.

Peer-review: Externally peer-reviewed.

Author Contributions: Concept - N.G.P., N.S., G.Y.Y.; Data Collection and/or Processing - N.G.P., N.S., G.Y.Y.; Analysis and/or Interpretation N.G.P., N.S., G.Y.Y.; Literature Search - N.G.P., N.S., G.Y.Y.; Writing - N.G.P., N.S., G.Y.Y.

Conflict of Interest: The authors have no conflict of interest to declare.

Financial Disclosure: The authors declared that this study has received no financial support.

\section{KAYNAKLAR}

1. Cabiedes J, Nûnez-Ălvarez CA. Antinuclear antibodies. Reumatol Clin 2010; 6(4): 224-30. [CrossRef]

2. Tan EM, Chan EK, Sullivan KF, Rubin RL. Antinuclear antibodies (ANAs): diagnostically specific immune markers and clues toward the understanding of systemic autoimmunity. Clin Immunol Immunopathol 1988; 47(2) :121-41. [CrossRef]

3. Birtane M. Diagnostic role of anti-nuclear antibodies in rheumatic diseases. Turk J Rheumatol 2012; 27(2): 79-9. [CrossRef]

4. Zandman-Goddard G, Shoenfeld Y. HIV and autoimmunity. Autoimmunity Reviews 2002; 1: 329-37. [CrossRef]

5. Mc Murray RW, Elbourne K. Hepatitis C virus infection and autoimmunity. Semin Arthritis Rheum 1997; 26(4): 689-01. [CrossRef]

6. Torchilin VP, lakoubov LZ, Estrov Z. Antinuclear autoantibodies as potential antineoplastic agents. Trends Immunol 2001; 22(8): 4247. [CrossRef]

7. Shoenfeld $Y$, Zandman - Goddard G editors. Autoimmune diseases- The enemy from within. USA, Bio-Rad Laboratories. 1 st ed. 2003.
8. Kavanaugh A, Tomar R, Reveille J, Solomon DH, Homburger HA. Guidelines for clinical use of the antinuclear antibody test and tests for specific autoantibodies to nuclear antigens. American College of Pathologists. Arch Pathol Lab Med 2000; 124(1): 71-1.

9. Bradwell AR, Stokes RP, Johnson GD editors. Atlas of autoantibody patterns on tissues. KNP Group Ltd, England 1997; (5): 27-51.

10. Csernok E. Anti-neutrophil cytoplasmic antibodies and pathogenesis of small vessel vasculitides. Autoimmun Rev 2003; 2(3): 15864. [CrossRef]

11. Smeenk RJ. Antinuclear antibodies: cause of disease or caused by disease? Rheumatology 2000; 39(6): 581-4. [CrossRef]

12. Egner W. The use of laboratory tests in the diagnosis of SLE. J Clin Pathol 2000; 53(6): 424-32. [CrossRef]

13. Tan EM, Feltkamp TE, Smolen JS, Butcher B, Dawkins R, Fritzler MJ, et al. Range of antinuclear antibodies in "healthy" individuals. Arthritis Rheum 1997; 40(9): 1601-11. [CrossRef]

14. Cabral DA, Petty RE, Fung M, Malleson PN. Persistent antinuclear antibodies in children without identifiable inflammatory rheumatic or autoimmune disease. Pediatrics 1992; 89(3): 441-4.

15. Deane PM, Liard G, Siegel DM, Baum J. The outcome of children referred to a pediatric rheumatology clinic with a positive antinuclear antibody test but without an autoimmune disease. Pediatrics 1995; 95(6): 892-5.

16. Autoimmune disease in women- the facts. URL:http:// www.aarda.org/women

17. Yurttutan-Uyar N, Güngör Ö, Serteser M, Akyar I. Antinükleer antikor-hep-2 (ANA) testinin tarama titresi için pozitiflik değerinin belirlenmesi. Turk Hij Den Biyol Derg 2017; 74(1): 13-20. [CrossRef]

18. Zola H, Roberts-Thomson P, McEvoy R editors . Diagnostic immunopathology. Laboratory practice and clinical application. New York: Cambridge University Press 1995; (4): 62-112.

19. Peene I, Meheus L, Veys EM, De Keyser F. Detection and identification of antinuclear antibodies (ANA) in a large and consecutive cohort of serum samples referred for ANA testing. Ann Rheum Dis 2001; 60(12): 1131-6. [CrossRef]

20. Bradwel A R, Hughes R G, Harden E L editors. Atlas of Hep-2 patterns. Drapkins Co. UK.2nd ed. 2003, p 116.

21. Bradwell A R, Stokes R P, Mead G P editors. Advanced atlas of autoantibody patterns. KNP Group Ltd, England. 1999; 29.

22. Zauli D, Cassani F, Bianchi FB. Auto-antibodies in hepatitis C. Biomed Pharmacother 1999; 53(5-6): 234-41. [CrossRef]

23. Worman HJ, Courvalin JC. Antinuclear antibodies specific for primary biliary cirrhosis. Autoimmun Rev 2003; 2(4): 211-17. [CrossRef]

24. Kamalı S, Kasapoğlu E, Çefle A, Sayarlıŏlu M, Öcal L, Gül A, İnanç $\mathrm{M}$, Aral O, Koniçe M. Primer Sjögren sendromu 35 hastanın klinik ve laboratuar özellikleri: İstanbul Tıp Fakültesi Romatoloji Bilim Dalı Tecrübesi. İst Tıp Fak. Mecmuası 2004; 67(2): 105-8.

25. Yılmaz Ö, Karaman M, Ergon MC, Bahar İH, Yuluğ N. Konnektif doku hastalıklarının tanısında antinükleer (ANA) ve anti-double stranded DNA (anti-dsDNA) antikorlarının önemi. Türkiye Parazitol Dergi 2005; 29(4): 287-90.

26. Yumuk Z, Çalışkan Ş, Gündeş S, Willke A. Anti-nükleer antikorların (ANA) araştırılması ve saptanmasında kullanılan teknikler. Türk Microbiol Cem Dergi 2005; 35(1): 40-4. 